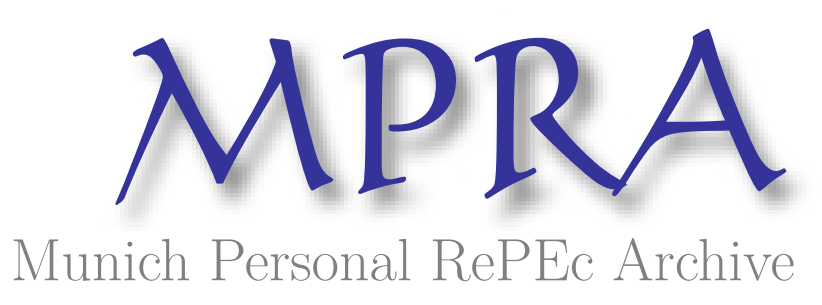

Non-performing loans in European systemic and non-systemic banks

Ozili, Peterson K

2019

Online at https://mpra.ub.uni-muenchen.de/94008/

MPRA Paper No. 94008, posted 19 May 2019 21:33 UTC 


\title{
Non-performing loans in European systemic and non-systemic banks
}

\author{
P. K. Ozili
}

\begin{abstract}
The distinction between GSIBs (systemic banks) and non GSIBs (non-systemic banks) is driven by policy reasons. I examine the behaviour of non-performing loans in European systemic and non-systemic banks, and find that more profitable banks witness higher non-performing loans regardless of whether they are systemic or non-systemic. Systemic banks have fewer nonperforming loans during economic booms and during periods of increased lending while nonsystemic banks experience higher NPLs during periods of increased lending. I also observe that European non-systemic banks that exceed regulatory capital requirements have higher NPLs. In the post-2007 financial crisis period, the NPL of systemic banks is negatively associated with the economic cycle which imply that the NPL of systemic banks is procyclical with the state of the economy, and the NPL of systemic banks are positively associated with loan supply and bank profitability. On the other hand, the NPL of non-systemic banks is negatively associated with regulatory capital ratios, and is positively associated with bank profitability for non-systemic banks in the post-2007 financial crisis period. The findings have implications.
\end{abstract}

JEL codes: C33, E44, G21

Keywords: credit risk, non-performing loans, systemic banks, systemic risk, impaired loans, asset quality; European banks, Europe, bank profitability.

This Version: 2019

I thank the editors, and two anonymous reviewers for constructive feedback, as well as offering support throughout the review process.

The views expressed are those of the author(s) and do not necessarily represent the views of the institution(s) the author is affiliated with.

Cite as: “Ozili, P.K. (2019). Nonperforming loans in European systemic and non-systemic banks. Journal of Financial Economic Policy." 


\section{Introduction}

This study investigates the behaviour of non-performing loans, focusing on the relationship between non-performing loans (NPLs) and the economic cycle for European systemic and nonsystemic banks. The distinction between systemic banks (GSIBs) and non-systemic (non GSIBs) is driven by policy reasons. In Europe, banking policy makers have growing concern for high non-performing loans in the EU banking sector due to the interdependence between bank financing and economic growth in the European Union (European Commission, 2013, 2014). Also, high levels of NPLs in the European banking sector pose significant risks to financial stability in the EU. The current levels of NPLs piled up in several parts of the EU banking sector are the aftermath of the global financial crisis and sovereign crisis in recent years (European Commission, 2018). Aiyar et al (2015), in an IMF study, show that non-performing loans in the European Union (EU) stood at about $€ 1$ trillion (equivalent to over 9 percent of the GDP of the entire EU region) at the end of 2014 - more than double the level in 2009. They point out that some structural obstacles in the EU banking system discouraged EU banks from addressing their non-performing loan problems, such as prudential supervision issues, legal obstacles, distressed debt markets, informational obstacles, tax and other obstacles.

In addition to these issues, the credit risk of a systemic financial institution in the financial system is crucial for financial system stability. A financial system regulator should be worried if the top ten largest industry obligors or debtors are indebted to systemic banks especially when these loans are non-performing. When high NPLs are concentrated among systemic financial institutions, such losses will be charged against bank profits and can erode bank capital, and the loss of bank capital can lead of the collapse of any financial institution. In recent times, systemic European banks that have serious NPL problems often seek regulatory forbearance from regulators which is a way for them to have more time to deal with their NPL problems.

This study focus on the behaviour of NPLs in European systemic and non-systemic banks because of the systemic risk that distressed too-big-to-fail financial institutions may pose to the entire financial system. The collapse of a systemic bank can collapse the entire financial system, and non-performing loans can trigger the failure of a bank. Excess non-performing loans in systemic banks can (i) send the wrong signal to outsiders about the stability of other banks connected to systemic banks (ii) and can bring down any financial institutions if the losses completely wipe out the capital of the bank. Therefore, it is in the best interest of EU policy makers to understand this signalling problem, and they need to address the rising NPL issues in the European banking sector. One way to understand the behaviour of NPLs is to first identify the determinants of NPLs in banks. Prior studies have identified some determinants such as business cycle fluctuation, regulatory capital ratios, loan growth, etc. (see Nkusu 2011; Louzis et al, 2012; Klein 2013; Ozili, 2019, etc.). The next question is: do these determinants have similar or dissimilar impact on systemic versus non-systemic banks? If yes, how and why? Under what economic (or bank-specific) conditions do systemic banks experience higher or fewer NPLs, as well as for non-systemic banks.

This study adopts the Financial Stability Board (FSB) and Basel Committee for Banking Supervision (BCBS)'s distinction between systemic banks (GSIBs) and (non-GSIBs). This classification is used to analyse the behaviour of nonperforming loans in the two bank groups. 
I analyse European banks over the 2004 to 2013 period, and find that more profitable banks witness higher non-performing loans. Systemic banks have fewer non-performing loans during economic booms and during periods of increased lending while non-systemic banks experience higher NPLs during periods of increased lending. The findings also reveal that systemic banks keep higher regulatory capital ratios when they expect higher NPLs while nonsystemic banks that exceed regulatory capital requirements experience higher NPLs.

The study contributes to the literature in the following way. First, this study contributes to the recent literature on the determinants of non-performing loan (Espinoza and Prasad, 2010; Fofack, 2005; Louzis et al, 2012; Ozili, 2019). This study adds to this literature by analysing the link between non-performing loans and the business cycle, focussing on systemic banks and nonsystemic banks in Europe. An investigation into the behaviour of NPLs in systemic and nonsystemic banks is useful for micro-prudential regulation to help EU policy makers understand the implication of large non-performing exposures in systemic and non-systemic banks. Secondly, the analysis in this paper is useful to provide additional insights on the link between problem loans and various states of the economy. Thirdly, this study can help policy makers understand how non-performing loans builds-up in systemic financial institutions in order to devise pro-active policy response to quickly address the NPL issues in systemic banks in Europe.

The rest of the paper is organised as follows. Section 2 discuss the literature review on the determinants of non-performing loans. Section 3 presents the data. Section 4 discuss the research design and methodology. Section 5 discuss the empirical results. Section 6 concludes.

\section{Related Literature}

\subsection{Measuring Systemic risk}

A widely used measure of systemic risk is the conditional value-at-risk (CoVaR) proposed by Adrian and Brunnermeier (2011) which capture risk spill-overs among financial institutions. The CoVar is the value-at-risk $(\mathrm{VaR})$ of the financial system conditional on one institution being in distress (Karimalis and Nomikos, 2018). Another measure of systemic risk is the 'distressed insurance premium' (DIP) measure. The distressed insurance premium (DIP) is a hypothetical insurance premium to cover losses that exceed a certain threshold of banks' total liabilities (Huang et al, 2009; Huang et al, 2012). The higher the losses or risk of the bank, the higher the distressed insurance premium. Black et al (2013) applied the DIP approach to evaluate systemic risk in the European banking sector. The third measure of systemic risk is the CATFIN. CATFIN is an aggregate measure of systemic risk in the financial sector. It measures the detrimental effects of financial risk taking by the overall financial sector on the macroeconomy (see Allen et al 2012). The CATFIN focus on forecasting macroeconomic developments in the economy when measuring systemic risk. (Karimalis and Nomikos, 2018). CATFIN is estimated using both value-at-risk (VaR) and expected shortfall (ES) methodologies, each of which are estimated using three approaches: one non-parametric and two different parametric specifications. In comparison, the CATFIN attempts to predict or forecast the macroeconomic systemic risk in the financial sector while the CoVaR and DIP only measure the cross-sectional (bank-level) differences in banks' contribution to systemic risk (Allen et al, 2012). 
Another systemic risk measure is the component expected shortfall (Banulescu and Dumitrescu, 2015). The component expected shortfall (CES) decompose the risk of the aggregate financial system into several components while accounting for firm characteristics. The CES assess the contribution of a firm to systemic risk at a precise date but also to forecast its contribution over a certain period (Banulescu and Dumitrescu, 2015). The CES is a hybrid measure that combines the 'Too-Interconnected-To Fail' and the 'Too-Big-To-Fail' logics. Also, CES relies only on publicly available daily data and is similar to the popular 'Marginal Expected Shortfall' measure. Another measure of systemic risk is the systemic expected shortfall (SES) by Acharya et al. (2010). The SES is the expected capital shortage of an individual firm conditional on a substantial reduction of the capitalization of the entire system. Under a number of assumptions, SES can be expressed as a linear combination of marginal expected shortfall (MES) and leverage where the parameters of such a combination are not known in general (Brownlees and Engle, 2012). Another measure is the 'SRISK' which measures the amount of capital an institution would need to survive a capital shortage in the financial system. It is the amount of capital that a firm would need to survive when the entire system is undercapitalised (Brownlees and Engle, 2012). Similarly, aggregate SRISK is the total amount of capital that the government would need to provide to bailout the financial system in the event of a crisis (Brownlees and Engle, 2012). Other measures include the marginal expected shortfall, etc.

Finally, systemic risk can be measured by whether a financial institution is a global systemically important financial institution or whether it is a non-global systemically important financial institution. The Financial Stability Board (FSB) in 2013 developed a classification for identifying financial institutions that pose the greatest risks to the global financial system. They proposed a G-SIB classification which classify all financial institutions according to their systemic risk contribution to the global financial system. The criteria to determine whether a financial institution is a GSIBs is based on a financial institution (FI)'s size, interconnectedness, complexity, non-substitutability and cross-border activities (or global reach). This study adopts the G-SIB classification to analyse the behaviour of non-performing loans in banks.

\subsection{NPLs and Systemic Risk Regulation - Theoretical Perspectives}

Prior to the distinction between G-SIBs vs non-GSIBs by the FSB/BCBS, the Basel risk-capital regulation was adopted for mitigating credit risk in banks (Benink and Wihlborg, 2002; Basel II, 2004). Risk-capital regulation is achieved through the allocation of capital for all risky and significant activities in financial institutions (Shrieves and Dahl, 1992; Besanko and Kanatas, 1996). For NPLs, the incurred loss provisioning model has traditionally been used to allocate loan loss provisions as a cushion to absorb nonperforming loans when they become doubtful, substandard or lost. Generally, the use of provisioning and risk-capital has been a fundamental principle of Basel regulations even though critics argue that risk-capital and provisioning are two sub-optimal solutions to mitigate bank risks because they only focus on risks arising from banking activities rather than focusing on the root cause of risks in banks. However, there are some disagreement in the literature regarding the risk-sensitivity of risk-capital regulation. For instance, Bleck (2018) argues that when a bank is better informed about its risk than the regulator, any regulation designed to regulate banks would be subject to the Lucas critique. Bleck (2018), building on the Lucas critique, argue that banks know and understand their risk better than regulators, therefore, bank risk-capital regulations are a second-best regulation and might be insensitive to risk. Bleck (2018) supports a leverage ratio-based 
regulation, and suggest that the leverage ratio of financial institutions might be a better measure for systemic riskiness than risk-based capital regulation.

\subsection{Empirical Literature}

High NPL ratios can affect bank's short-term and long-term performance through two main channels. First, NPLs generate less income for banks thereby reducing bank profitability and can diminish bank capital when non-performing loans are written-off. In severe cases, high NPLs can make a bank become insolvent. Secondly, high NPLs tie up significant amount of banks' resources, both human and financial, making it difficult for banks to provide new credit to businesses and individuals (European Commission, 2018).

Studies linking credit risk to the state of the economy are not new in the literature (e.g. Carey, 1998; Ruckes, 2004; Salas and Saurina, 2002; Fofack, 2005; Louzis et al, 2012; Ozili and Thankom, 2018). These studies show that in good economic times, banks extend credit to low quality debtors in order to generate higher revenue because the risk of financial distress is usually low during boom years. However, when a recession sets in, non-performing loans are expected to increase for banks. Pesaran (2006) examine the link between changes in credit portfolio and the macroeconomy, and observe that loan default probabilities are strongly driven by the link between firms and the economic cycle, implying that historical data on default probabilities can help predict the likelihood of future non-performing loans. However, data on default probabilities may be difficult to assess for decision making by outsiders. Beck et al (2013) also confirm that data on default probabilities are largely unavailable publicly.

Other studies also use non-performing loan as a measure of bank credit risk. Nkusu (2011), in a panel data analyses, examine the relationship between banks' loan portfolio quality and macro financial vulnerabilities for 26 countries during 1998 to 2009. Nkusu find a positive relationship between asset quality and the macroeconomic variables used in the study. Glen and Mondragón-Vélez (2011) examine banks from 22 developed countries from 1996 to 2008 and observe that loan loss provisions (a proxy for credit risk) is driven by real GDP growth as well as, low bank capitalisation and private sector leverage. Similarly, Pesola (2005) find a strong link between credit risk and the macroeconomic environment while Drehmann (2005) show that the link between credit risk and macroeconomic shocks may be non-linear. Cihak (2007) and Wezel et al (2014) in their stress-testing analyses examine the resilience of bank balance sheet to adverse economic conditions. These studies suggest that credit risk is strongly linked to changes in the economic cycle.

Much of the studies that link credit risk or non-performing loans to the state of the economy are mainly country specific studies. For instance, Salas and Saurina (2002) investigate the determinants of problem loans in Spanish commercial and savings banks while controlling for other factors such as capital ratio, bank size net interest margin and market power. They find that problem loans are strongly linked to the economic cycle (i.e., real GDP growth). Quagliarello (2007) observe that the state of the economy is a determinant of non-performing loans for Italian banks. Klein (2013) also document a strong negative relationship between nonperforming loans and the economic cycle proxy by change in gross domestic product for banks in Central, Eastern and South- Eastern Europe (CESEE) countries. Fofack (2005) find similar evidence for banks in sub-Saharan African countries while Louzis et al (2012) find similar 
evidence in the Greek banking sector. Prior literature has not focussed on the link between nonperforming loans and the economic cycle for systemic banks compared to non-systemic banks. This present study, in contrast, examine two categories of European banks: systemic banks and non-systemic banks.

\section{Data}

Pooled cross-section and time series balance sheet data for European banks are obtained from the Van Dijk Bankscope database for 16 counties in Europe: United Kingdom, Germany, Ireland, Luxemburg, Norway, Denmark, Finland, Greece, Portugal, Belgium, Netherland, Sweden, Spain, France, Italy and Austria. The sample period covers 2004 to 2013. The rationale for the choice of sample period is to allows us cross-check how the 2007-2008 financial crisis affected systemic and non-systemic banks and also how they have changed since the crisis. Also, since the 2004 to 2013 period precede the date the European Central Bank (ECB) assumed responsibility for the Euro Area banking sector in November 4, 2014, the current sample period will allow us to capture the behaviour of NPLs before the European Central Bank (ECB) intervention. To control for the 2008 financial crisis, 2008 bank-year observations are eliminated so that the impact of the financial crisis would not affect the validity our inference(s). A binary dummy variable is introduced to distinguish between the pre-crisis and the post-crisis period. Data for real gross domestic product growth rate, a proxy for economic cycle, is obtained from the World Economic Forum database. The $\triangle$ GDP data allows us to detect whether the magnitude of non-performing loans and its link to the economic cycle during the period warranted the full intervention of the European Central Bank in the first place. For our purpose, the European banks are then divided into systemic (G-SIBs) and non-systemic banks (non-G-SIBs). The distinction between systemic and non-systemic banks is based on the joint Financial Stability Board (FSB) and Basel BCBS's classification of banks as global systemically-important banks (G-SIBs). Banks that are not classified as global systemic banks in 2013 year-end are considered to be nonsystemic banks. This is the only distinction made between banks in this study. The resulting final sample yields 231 European bank sample containing 41 systemic banks and 190 non-systemic banks as shown in Appendix A1. All sample banks have December 31 fiscal year ends. The data is an unbalanced panel.

\section{Methodology}

The multivariate model employed to investigate the relationship between non-performing loans and the economic cycle is a variation of the model used by Beck et al (2013) and Ozili (2019) who examine the determinants of non-performing loans. The functional form of the model in this study is given as

$$
\begin{gathered}
\text { NPLit }=\beta 0+ \\
+\beta 1 \text { LOANit }+\beta 2 \text { CARit }+\beta 3 \text { EBTPit }+\beta G D P i, t-1+\beta 5 \text { GDPit } \\
+ \text { PERIODdummies }+ \text { eit } .
\end{gathered}
$$

Where

NPL = Non-performing loan to gross loan ratio for bank $i$ at time $t$. 
LOAN = Change in gross loan outstanding for bank $i$ at time $t$

CAR $=$ ratio of Tier 1 capital divided by risk-weighted assets for bank $i$ at time $t$.

EBTP = ratio of earnings before tax and loan loss allowance divided by total assets for bank $i$ at time t.

$\Delta G D P=$ Real gross domestic product growth rate.

The Non-performing loans to gross loans ratio is the dependent variable and the measure of asset quality in the study. The explanatory variables are LOAN, CAR, EBTP and $\triangle$ GDP. The LOAN variable is introduced to control for the influence of bank lending on non-performing loans. $A$ negative sign for the LOAN coefficient is expected. The second explanatory variable is regulatory capital ratio. Banks that keep higher regulatory capital ratios will restrain from engaging in risky lending thereby minimising the amount of problem loans in their balance sheet, which improves asset quality. When this is the case, a negative relationship between NPL and CAR is expected. However, a positive relationship may be expected if banks that engage in risky lending anticipate their high risks and keep more regulatory capital to compensate for their high risk activities. The third explanatory variable is real gross domestic product growth rate ( $\triangle \mathrm{GDP}$ ). The real gross domestic product growth rate variable measures the impact of economic cycle fluctuation on bank non-performing loans. A negative relationship is predicted between NPLs and $\triangle$ GDP because NPLs tend to be higher (lower) during recessions (booms). The fourth explanatory variable is the earnings variable (EBTP). The earnings before tax and provisions (EBTP) variable measures the association between non-performing loans and bank earnings before loan loss provisions. A negative relationship between NPL and EBTP is expected because high NPLs will be written-off as losses which will reduce bank profit.

Further tests are conducted: to determine whether the relationship between asset quality (non-performing loans) and earnings is stronger when earnings (before loan loss adjustment) are negative or high (substantial). To test for this, two dummy variables are introduced into the model: 'POS' dummy variable that take the value ' 1 ' when EBTP is above-the-median EBTP ratio and zero otherwise; and 'NEG' dummy variable take the value ' 1 ' when EBTP is a negative number and zero otherwise. These two dummies are then interacted with the EBTP variable. Inference is then drawn from the relationship between NPLs and 'NEG*EBTP' and 'POS*EBTP earnings interaction terms. Additionally, I test whether banks with above $8 \%$ tier 1 capital report higher or fewer non-performing loans. This test allows us to determine whether nonperforming loans improves with sufficient or insufficient Tier 1 capital ratios. To test for this, the 'WELL' dummy variable is introduced into the model which take the value ' 1 ' if CAR is above $8 \%$ and zero otherwise. The 'WELL' dummy is then interacted with the 'CAR' variable. Finally, I test whether positive increase in bank lending is significantly associated with nonperforming loans. To test for this, I take the natural logarithm of the LOAN variable to capture only the positive increase in outstanding loans over the period. Taking the natural logarithm of the LOAN variable In(LOAN) systematically eliminates the negative observations in the time series distribution for the LOAN variables but retains all the positive observations of the LOAN variable. Inference is then drawn from the relationship between NPL and $\ln ($ LOAN).

The model is estimated using panel data regression. The method of analysis follows a dynamic specification of the model. The dynamic model includes the lagged dependent variable as an 
explanatory variable in order to capture the persistence of NPL growth over time. Also, the introduction of the lagged dependent variable into the model makes it inappropriate to estimate the model using fixed effect least square regression approach. The Generalised-Method of Moments (GMM) method with instrumental variables is considered to be more appropriate to estimate the model. I use the Generalised Method of Moments (GMM) regression estimation based on the approach of Arellano and Bond (1991). Beck et al (2013) and Ozili and Thankom (2018) also use this approach. The AR (1) and AR (2) are Arellano-Bond GMM tests for first and second order serial-correlation of the residuals. In the analysis, the number of instruments is below the number of cross-section. The next section presents the results.

\section{Empirical Results}

\subsection{Descriptive statistics and Correlations}

Table 1 provides the summary of the descriptive statistics for systemic and non-systemic banks for the 2004 to 2013 period. Regarding non-performing loans, NPLs are, on average, $4.51 \%$ for the full sample, $3.46 \%$ for systemic banks and $4.76 \%$ for non-systemic banks, respectively, implying that systemic banks report fewer NPLs, on average, and might suggest that systemic banks have better asset quality than non-systemic banks. Improved credit risk management by systemic banks can lower their credit risk exposure and reduce the amount of regulatory capital (Tier 1 capital) they need to set aside for the risks they take. Unsurprisingly, systemic banks report a low CAR (10.48\%) compared to non-systemic banks (11.18\%). Regarding credit growth (LOAN), LOANs are $5.34 \%$ for the entire bank sample and systemic banks record lower growth in loans at $4.38 \%$ while non-systemic banks have about $5.55 \%$. Finally, the difference of means between systemic and non-systemic banks is low.

\begin{tabular}{|c|c|c|c|c|c|c|c|}
\hline \multicolumn{8}{|c|}{ Table 1: Descriptive statistics: Systemic vs Non Systemic Banks } \\
\hline & \multicolumn{2}{|c|}{ Full Sample } & \multicolumn{2}{|c|}{$\begin{array}{l}\text { Systemic } \\
\text { Banks }\end{array}$} & \multicolumn{2}{|c|}{$\begin{array}{c}\text { Non-Systemic } \\
\text { Banks }\end{array}$} & \multirow[t]{2}{*}{$\begin{array}{c}\text { Difference } \\
\text { of Means }\end{array}$} \\
\hline & Mean & S.D & Mean & S.D & Mean & S.D & \\
\hline NPL & 4.513 & 5.44 & 3.456 & 2.989 & 4.762 & 5.848 & -1.306 \\
\hline LOAN & 5.340 & 16.726 & 4.384 & 18.06 & 5.550 & 16.418 & -1.166 \\
\hline CAR & 11.053 & 4.819 & 10.481 & 2.851 & 11.183 & 5.117 & -0.702 \\
\hline EBTP & 0.008 & 0.009 & 0.009 & 0.008 & 0.008 & 0.010 & 0.001 \\
\hline No of Banks & \multicolumn{2}{|c|}{23} & \multicolumn{2}{|c|}{41} & \multicolumn{2}{|c|}{190} & \\
\hline \multicolumn{8}{|c|}{$\begin{array}{l}\text { *S. D - Standard Deviation. Table } 1 \text { report the descriptive statistics obtained } \\
\text { from } 231 \text { bank samples from } 16 \text { European countries. Data cover the period } \\
2004 \text { to } 2013 . \text { NPL is non-performing loans to gross loan. EBTP is earnings } \\
\text { before taxes and provision to total assets. LOAN is the change in gross loan. } \\
\text { CAR is bank capital divided by risk-weighted assets. } \triangle \text { GDP is real gross } \\
\text { domestic product growth rate. }\end{array}$} \\
\hline
\end{tabular}


Panel $2 \mathrm{~A}$ and $\mathrm{B}$ reports the Pearson correlation coefficients and the associated $\mathrm{p}$-values. Panel $2 a$ reports the correlation results for systemic banks. NPLs are not significantly correlated with EBTP. LOAN is significant and negatively correlated with NPLs for systemic banks, implying that systemic banks that increase loan supply experience fewer non-performing loans. CAR is significant and positively correlated with NPLs for systemic banks, implying that well-capitalised systemic banks experience higher problem loans. $\triangle$ GDP is negative and significantly correlated with NPLs, implying that problem loans are higher during bad times.

Panel $2 b$ reports the correlation results for non-systemic banks. NPLs are not significantly correlated with EBTP. LOAN is significant and negatively correlated with NPLs for nonsystemic banks, implying that non-systemic banks that increase loan supply experience fewer non-performing loans. CAR is significant and negatively correlated with NPLs for nonsystemic banks, implying that well-capitalised non-systemic banks experience higher problem loans. $\triangle$ GDP is negative and significantly correlated with NPLs, implying that nonsystemic banks experience high problem loans during bad times. Overall, the correlation coefficients in Panel A and B are sufficiently low to be concerned about multi-collinearity in the study.

2a: Correlation for Systemic Banks

Panel B report the correlation matrix for systemic banks. All bank level variables remain as previously defined. ${ }^{\star \star \star}$, ** and ${ }^{*}$ represent significance at the $1 \%, 5 \%$ and $10 \%$ level, respectively. $\mathrm{P}$-values are reported in parentheses.

\begin{tabular}{c|ccccc}
\hline \hline Variable & NPL & LOAN & $\Delta$ GDP & EBTP & CAR \\
\hline NPL & 1.000 & & & & \\
& & & & & \\
LOAN & $-0.372^{\star \star \star}$ & 1.000 & & & \\
& $(0.000)$ & & & & \\
$\Delta$ GDP & $-0.245^{\star \star \star}$ & $0.321^{\star \star \star}$ & 1.000 & & \\
& $(0.000)$ & $(0.000)$ & & & \\
EBTP & 0.009 & $0.262^{\star \star \star}$ & -0.012 & 1.000 & \\
& $(0.893)$ & $(0.000)$ & $(0.862)$ & & \\
CAR & $0.187^{\star \star \star}$ & $-0.394^{\star \star \star}$ & $-0.253^{\star \star \star}$ & $-0.335^{\star \star \star}$ & 1.000 \\
& $(0.005)$ & $(0.000)$ & $(0.000)$ & $(0.000)$ & \\
\hline \hline
\end{tabular}


Panel 2b: Correlation for Non-Systemic Banks Panel $C$ report the correlation matrix for non G-SIBs. All bank level variables remain as previously defined. ${ }^{\star \star \star},{ }^{* \star}$ and ${ }^{*}$ represent significance at the $1 \%, 5 \%$ and $10 \%$ level, respectively. $\mathrm{P}$-values are reported in parentheses.

\begin{tabular}{c|ccccc}
\hline \hline Variable & NPL & LOAN & $\Delta$ GDP & EBTP & CAR \\
\hline NPL & 1.000 & & & & \\
LOAN & & & & & \\
& $-0.221^{\star \star \star}$ & 1.000 & & & \\
& $(0.000)$ & & & & \\
$\Delta$ GDP & $-0.279^{\star \star \star}$ & $0.234^{\star \star \star}$ & 1.000 & & \\
& $(0.000)$ & $(0.000)$ & & & \\
EBTP & -0.032 & $0.246^{\star \star \star}$ & $0.144^{\star \star \star}$ & 1.000 & \\
& $(0.334)$ & $(0.000)$ & $(0.000)$ & & \\
CAR & $-0.065^{\star \star}$ & $-0.248^{\star \star \star}$ & -0.041 & -0.051 & 1.000 \\
& $(0.047)$ & $(0.000)$ & $(0.204)$ & $(0.119)$ & \\
\hline \hline
\end{tabular}

\subsection{Regression Result}

\subsubsection{Full Sample Analysis}

Column 1 of Table 3 and 4 report the dynamic (Arellano-Bond) regression estimations for systemic banks and non-systemic banks. $\triangle$ GDP coefficient is negatively significant, implying that systemic banks witness fewer NPLs during economic booms. But, the result is not significant for non-systemic banks. This finding is similar with the result of Glen and Mondragón-Vélez (2011) and Nkusu (2011) who show a link between non-performing loan and $\triangle G D P$. The lagged GDP growth coefficient is negatively significant for both systemic and nonsystemic banks, indicating that lagged GDP growth is inversely and significantly associated with growth of NPLs for both banks. This implies that banks' asset quality deteriorates with a lag in response to negative economic growth possibly due to the difficulty of debtors to meet their obligation during bad economic times. The earnings coefficient (EBTP) reports a negative sign for both banks although the result is weakly significant for systemic banks and insignificant for non-systemic banks. This implies that NPLs are likely to impair the earnings of systemic banks than non-systemic European banks, however, the results do not show a strong link between NPLs and earnings before loan loss allowance (EBTP). Also, loan growth (LOAN) has a negative and significant impact on the non-performing loans of systemic banks. This suggest that systemic banks lend to less-risky borrowers, which leads to lower NPLs, and imply that systemic banks probably have a strong and prudent credit risk management system compared to non-systemic banks. Similarly, a negative relationship between NPLs and LOAN 
is observed for non-systemic banks but this relationship is insignificant. Finally, the CAR coefficient is positive and significant for systemic banks but is insignificant for non-systemic banks, indicating that systemic banks keep higher regulatory capital when they expect higher NPLs.

\subsubsection{Behaviour of NPLs after the global financial crisis}

Here, I introduce the 'POST' dummy variable that take the value ' 1 ' for the post-financial crisis period and ' $O$ ' otherwise. I interact the 'POST' variable with the NPL determinants in the model to determine their effect on NPLs. The result is reported in column 2 to 5 of Table 3 and 4. For systemic banks, NPL has a significant and negative relationship with the economic cycle in the post-financial crisis period, implying that systemic banks tend to have higher NPLs during economic recessions in the post-crisis period. On the other hand, NPL has a significant and positive relationship with earnings and bank lending in the post crisis period, implying that NPLs are higher among systemic banks that are profitable and among systemic banks with higher loan supply in the post-crisis period. For non-systemic banks, NPL has a significant and negative relationship with the regulatory capital in the post-financial crisis period, implying that non-systemic banks with lower regulatory capital have higher NPLs in the postcrisis period. On the other hand, NPL has a significant and positive relationship with earnings, implying that NPLs are higher among non-systemic banks that are profitable in the post-crisis period. Overall, the post-crisis findings for systemic banks shows that regulatory capital (CAR) did not have a significant effect on NPLs, and suggests that risk-capital regulation might be insensitive to risk in systemic banks, which supports the argument of Bleck (2018). 


\begin{tabular}{|c|c|c|c|c|c|}
\hline \multicolumn{6}{|c|}{ Table 3. European Systemic Banks } \\
\hline \multicolumn{6}{|c|}{ Arellano-Bond (1991) GMM estimation } \\
\hline & $(1)$ & $(2)$ & $(3)$ & (4) & (5) \\
\hline NPLt-1 & $\begin{array}{c}0.602^{\star \star \star} \\
(9.13)\end{array}$ & $\begin{array}{c}0.567^{\star \star \star} \\
(11.04)\end{array}$ & $\begin{array}{c}0.583^{\star \star \star} \\
(10.49)\end{array}$ & $\begin{array}{l}0.540 \\
(9.16)\end{array}$ & $\begin{array}{c}0.515^{\star \star \star} \\
(8.97)\end{array}$ \\
\hline EBTP & $\begin{array}{c}-30.509^{\star} \\
(-1.69)\end{array}$ & $\begin{array}{l}15.02 \\
(0.74) \\
\end{array}$ & $\begin{array}{c}-63.95^{\star \star \star} \\
(-3.49)\end{array}$ & $\begin{array}{l}15.33 \\
(0.82) \\
\end{array}$ & $\begin{array}{l}0.667 \\
(0.04) \\
\end{array}$ \\
\hline LOAN & $\begin{array}{c}-0.026^{\star \star \star} \\
(-3.91)\end{array}$ & $\begin{array}{c}-0.028^{\star \star \star} \\
(-2.59)\end{array}$ & $\begin{array}{c}-0.024^{\star \star \star} \\
(-3.57)\end{array}$ & $\begin{array}{c}-0.026^{\star \star \star} \\
(-3.33)\end{array}$ & $\begin{array}{c}- \\
0.035^{\star \star \star} \\
(-5.62)\end{array}$ \\
\hline CAR & $\begin{array}{l}0.112^{\star} \\
(1.72)\end{array}$ & $\begin{array}{l}0.06 \\
(1.18) \\
\end{array}$ & $\begin{array}{l}-0.006 \\
(-0.09)\end{array}$ & $\begin{array}{l}-0.065 \\
(-0.69)\end{array}$ & $\begin{array}{l}-0.045 \\
(-0.75)\end{array}$ \\
\hline$\triangle \mathrm{GDP}$ & $\begin{array}{c}-0.142^{\star \star \star} \\
(-2.88)\end{array}$ & $\begin{array}{c}0.931^{\star \star \star} \\
(5.93)\end{array}$ & $\begin{array}{l}-0.003 \\
(-0.04)\end{array}$ & $\begin{array}{l}0.042 \\
(0.56)\end{array}$ & $\begin{array}{l}-0.027 \\
(-0.31)\end{array}$ \\
\hline$\Delta \mathrm{GDPt}-1$ & $\begin{array}{c}-0.353^{\star \star \star} \\
(-5.47)\end{array}$ & $\begin{array}{l}-0.144^{\star} \\
(-1.84)\end{array}$ & $\begin{array}{l}-0.128^{\star} \\
(-1.75)\end{array}$ & $\begin{array}{l}-0.075 \\
(-0.97) \\
\end{array}$ & $\begin{array}{l}-0.095 \\
(-1.23) \\
\end{array}$ \\
\hline CRISIS & & $\begin{array}{c}4.620^{\star \star \star} \\
(6.47)\end{array}$ & $\begin{array}{l}1.247^{\star \star} \\
(2.04)\end{array}$ & $\begin{array}{c}2.783^{\star \star \star} \\
(3.36)\end{array}$ & $\begin{array}{c}2.210^{\star \star} \\
(2.42)\end{array}$ \\
\hline $\mathrm{CRISIS}^{\star} \Delta \mathrm{GDP}$ & & $\begin{array}{c}-0.928^{\star \star \star} \\
(-7.54)\end{array}$ & & & \\
\hline CRISIS*EBTP & & & $\begin{array}{c}102.06^{\star \star \star} \\
(5.01)\end{array}$ & & \\
\hline CRISIS*CAR & & & & $\begin{array}{l}0.025 \\
(0.31) \\
\end{array}$ & \\
\hline CRISIS*LOAN & & & & & $\begin{array}{c}0.022^{\star} \\
(1.81)\end{array}$ \\
\hline J-Statistic & 23.01 & 21.13 & 21.75 & 18.62 & 17.67 \\
\hline $\mathrm{P}(\mathrm{J}$-statistic) & 0.15 & 0.13 & 0.11 & 0.23 & 0.28 \\
\hline No of instrument & 30 & 30 & 30 & 30 & 30 \\
\hline $\mathrm{AR}(1)$ & 0.007 & 0.011 & 0.013 & 0.012 & 0.023 \\
\hline AR (2) & 0.899 & 0.199 & 0.236 & 0.407 & 0.475 \\
\hline $\begin{array}{l}\text { P-values in paren } \\
\text { levels, respective } \\
\text { instruments is aln } \\
\text { the Arellano-Bon } \\
\text { residuals, indicati } \\
\text { loan to gross loan } \\
\text { CAR = tierl capital } \\
\text { before tax and cre } \\
\text { growth rate. } \triangle \text { GDF } \\
\text { CRISIS = dummy v } \\
\text { and } 2013 \text { and zero }\end{array}$ & 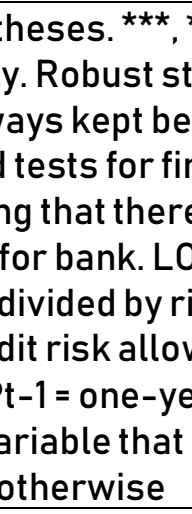 & $\begin{array}{l}{ }^{*} \text { and }{ }^{*} \text { deno } \\
\text { andard erro } \\
\text { ow the num } \\
\text { st and secor } \\
\text { is no serial } \\
\text { AN = change } \\
\text { sk-weightec } \\
\text { ance for ba } \\
\text { ar lagged gr } \\
\text { ake the valu }\end{array}$ & $\begin{array}{l}\text { e significan } \\
\text { is included. } \\
\text { er of group } \\
\text { d order auto } \\
\text { orrelation. } \\
\text { n gross loa } \\
\text { assets for b } \\
\text { k. } \Delta \text { GDP = G } \\
\text { ss domesti } \\
\text { of } 1 \text { for yea }\end{array}$ & $\begin{array}{l}\text { e at } 1 \%, 5 \% \text { c } \\
\text { The number } \\
\text { AR ( } 1 \text { ) and } \\
\text { correlation } \\
\text { JPL = Non-p } \\
\text { outstandin } \\
\text { ank. EBTP = } \\
\text { oss domest } \\
\text { product gr } \\
-2009,2010\end{array}$ & $\begin{array}{l}\text { nd } 10 \% \\
\text { of } \\
R(2) \text { are } \\
\text { f the } \\
\text { erforming } \\
\text { for bank. } \\
\text { arnings } \\
\text { c product } \\
\text { wth rate. } \\
2011,2012\end{array}$ \\
\hline
\end{tabular}




\begin{tabular}{|c|c|c|c|c|c|}
\hline \multicolumn{6}{|c|}{ Table 4. European Non Systemic Banks } \\
\hline \multicolumn{6}{|c|}{ Arellano-Bond (1991) GMM estimation } \\
\hline & (1) & $(2)$ & (3) & (4) & $(5)$ \\
\hline NPLt-1 & $\begin{array}{l}0.766^{\star \star \star} \\
(12.59)\end{array}$ & $\begin{array}{l}0.742^{\star \star \star} \\
(9.63)\end{array}$ & $\begin{array}{l}0.731^{\star \star \star} \\
(10.50)\end{array}$ & $\begin{array}{l}0.759^{\star \star \star} \\
(10.40)\end{array}$ & $\begin{array}{l}0.799 \star \star \star \\
(11.38)\end{array}$ \\
\hline EBTP & $\begin{array}{l}-33.554 \\
(-1.45)\end{array}$ & $\begin{array}{l}-25.13 \\
(-1.03)\end{array}$ & $\begin{array}{l}-340.12^{\star \star \star} \\
(-3.56)\end{array}$ & $\begin{array}{l}-43.73 \\
(-1.50)\end{array}$ & $\begin{array}{l}-35.128 \\
(-1.56)\end{array}$ \\
\hline LOAN & $\begin{array}{l}-0.009 \\
(-0.77)\end{array}$ & $\begin{array}{l}-0.019 \\
(-1.39)\end{array}$ & $\begin{array}{l}-0.013 \\
(-0.72)\end{array}$ & $\begin{array}{l}-0.019 \\
(-0.93)\end{array}$ & $\begin{array}{l}-0.012 \\
(-0.35)\end{array}$ \\
\hline CAR & $\begin{array}{l}-0.060 \\
(-0.69)\end{array}$ & $\begin{array}{l}-0.216^{\star} \\
(-1.67) \\
\end{array}$ & $\begin{array}{l}0.133 \\
(0.83)\end{array}$ & $\begin{array}{l}1.373^{\star \star \star} \\
(3.94)\end{array}$ & $\begin{array}{l}-0.068 \\
(-0.63) \\
\end{array}$ \\
\hline$\triangle \mathrm{GDP}$ & $\begin{array}{l}0.183 \\
(1.57) \\
\end{array}$ & \begin{tabular}{|l|}
0.133 \\
$(0.72)$ \\
\end{tabular} & $\begin{array}{l}0.162 \\
(1.29)\end{array}$ & $\begin{array}{l}0.152 \\
(0.84)\end{array}$ & \begin{tabular}{|l|}
0.170 \\
$(1.22)$ \\
\end{tabular} \\
\hline$\Delta \mathrm{GDPt}-1$ & $\begin{array}{l}- \\
0.648^{\star \star \star} \\
(-5.60)\end{array}$ & $\begin{array}{l}-0.668^{\star \star \star} \\
(-5.81)\end{array}$ & $\begin{array}{l}-0.614^{\star \star \star} \\
(-4.79)\end{array}$ & $\begin{array}{l}-0.607^{\star \star \star} \\
(-5.32)\end{array}$ & \begin{tabular}{|l|}
-0.612 \\
$(-4.72)$
\end{tabular} \\
\hline CRISIS & & $\begin{array}{l}3.138 \\
(1.20)\end{array}$ & $\begin{array}{l}-10.469^{\star \star \star} \\
(-2.68)\end{array}$ & $\begin{array}{l}5.730 \\
(1.38)\end{array}$ & $\begin{array}{l}2.522 \\
(0.96)\end{array}$ \\
\hline $\mathrm{CRISIS}^{*} \Delta \mathrm{GDP}$ & & $\begin{array}{l}0.342 \\
(1.04)\end{array}$ & & & \\
\hline CRISIS*EBTP & & & $\begin{array}{l}297.23^{\star \star \star} \\
(3.30)\end{array}$ & & \\
\hline CRISIS*CAR & & & & $\begin{array}{l}-1.279^{\star \star \star} \\
(-4.14)\end{array}$ & \\
\hline CRISIS*LOAN & & & & & \begin{tabular}{|l|}
0.003 \\
$(-0.05)$ \\
\end{tabular} \\
\hline & & & & & \\
\hline J-Statistic & 33.03 & 30.69 & 24.10 & 21.59 & 31.63 \\
\hline $\mathrm{P}(\mathrm{J}-$ statistic $)$ & 0.06 & 0.06 & 0.23 & 0.36 & 0.05 \\
\hline No of instrument & 35 & 35 & 35 & 35 & 35 \\
\hline $\mathrm{AR}(1)$ & 0.0001 & 0.0001 & 0.0003 & 0.0004 & 0.001 \\
\hline AR (2) & 0.766 & 0.945 & 0.846 & 0.589 & 0.638 \\
\hline \multicolumn{6}{|c|}{$\begin{array}{l}\text { P-values in parentheses. }{ }^{\star \star \star},{ }^{* \star} \text { and }{ }^{*} \text { denote significance at } 1 \%, 5 \% \text { and } 10 \% \\
\text { levels, respectively. Robust standard error is included. The number of } \\
\text { instruments is always kept below the number of groups. AR (1) and AR (2) are } \\
\text { the Arellano-Bond tests for first and second order autocorrelation of the } \\
\text { residuals, indicating that there is no serial correlation. NPL = Non-performing } \\
\text { loan to gross loan for bank. LOAN = change in gross loan outstanding for bank. } \\
\text { CAR = tierl capital divided by risk-weighted assets for bank. EBTP = earnings } \\
\text { before tax and credit risk allowance for bank. } \triangle \text { GDP = Gross domestic product } \\
\text { growth rate. } \triangle \text { GDPt-1 = one-year lagged gross domestic product growth rate. } \\
\text { CRISIS = dummy variable that take the value of } 1 \text { for year-2009,2010, 2011, } 2012 \\
\text { and } 2013 \text { and zero otherwise. }\end{array}$} \\
\hline
\end{tabular}




\subsection{Further Analyses}

\subsubsection{Size of Earnings Effect}

Next, I analyse the behaviour of NPLs when banks have high profits or high loses. To test whether non-performing loans are significantly associated with earnings when both banks expect losses or high earnings, the NEG and POS dummy variables are interacted with EBTP. The result is reported in Column 1 and 5 of Table 5. The results show that NPLs are positive and strongly linked with EBTP when both banks are more profitable. This implies that, in the face of high non-performing loans (i.e., declining asset quality), both banks remain profitable (before adjustment for provisions) while column 2 and 6 show that NPLs are fewer for non-systemic banks when they experience higher losses, and insignificant for systemic banks.

\subsubsection{Higher Regulatory Capital Effect}

Next, I analyse the behaviour of NPLs when banks have sufficient (regulatory) capital. To test whether bank non-performing loans is significantly associated with Tier 1 capital when the banks have sufficient Tier 1 regulatory capital ratio (i.e., above $8 \%$ tier 1 capital), WELL dummy variable is interacted with the CAR variable. Column 3 report a negative relationship between NPLs and WELL ${ }^{\star} C A R$ for systemic banks but this relationship is not significant for systemic banks. One possible explanation for the weak relationship could be due to the fact that Tier 1 capital for systemic banks may be used more extensively to mitigate other risks (such as market risk, interest rate etc.) rather than to mitigate only credit risk. On the other hand, Column 7 report a positive and significant relationship between NPLs and above-8\% Tier 1 capital for non-systemic banks. This indicates that non-systemic banks with sufficient regulatory capital experience higher NPLs.

\subsubsection{Excess Credit Supply Effect}

Next, I analyse the behaviour of NPLs during periods of excess credit supply, or periods of increased lending. To test whether bank non-performing loan is significantly associated with positive credit growth, the natural logarithm of the LOAN variable is used. Inference is drawn based on the relationship between $\ln ($ LOAN) and NPLs. Column 4 and 8 report a negative relationship for systemic banks and a positive relationship for non-systemic banks, respectively, and both are significant at $10 \%$ level. The former indicates that increased bank lending for systemic banks leads to improved asset quality (fewer NPLs). This confirms the earlier result in Table 2. While the positive relationship for non-systemic banks indicate that non-systemic banks experience higher NPLs in response to increased lending among nonsystemic banks. This suggest that non-systemic banks engage in imprudent lending to borrowers which possibly leads to higher default by borrowers. 


\begin{tabular}{|c|c|c|c|c|c|c|c|c|}
\hline & \multicolumn{4}{|c|}{ Systemic Banks } & \multicolumn{4}{|c|}{ Non-systemic } \\
\hline & 1 & 2 & 3 & 4 & 5 & 6 & 7 & 8 \\
\hline NPLt-1 & $\begin{array}{c}0.583^{\star \star \star} \\
(7.56)\end{array}$ & $\begin{array}{c}0.586^{\star \star \star} \\
(8.49)\end{array}$ & $\begin{array}{c}0.701^{\star \star \star} \\
(9.62)\end{array}$ & $\begin{array}{c}0.743^{\star \star \star} \\
(9.68)\end{array}$ & $\begin{array}{c}0.794^{\star \star \star} \\
(12.48)\end{array}$ & $\begin{array}{c}0.863^{\star} \\
(1.87)\end{array}$ & $\begin{array}{c}0.697^{\star \star \star} \\
(8.77)\end{array}$ & $\begin{array}{c}0.994^{\star \star \star} \\
(11.13)\end{array}$ \\
\hline EBTP & $\begin{array}{c}-163.78^{\star \star \star} \\
(-4.03)\end{array}$ & $\begin{array}{l}-5.256 \\
(-0.25)\end{array}$ & $\begin{array}{c}-38.220 \\
(-1.47)\end{array}$ & $\begin{array}{c}-56.36^{\star \star} \\
(-2.01)\end{array}$ & $\begin{array}{c}-85.396^{\star \star \star} \\
(-3.59)\end{array}$ & $\begin{array}{c}184.42^{\star \star \star} \\
(2.52)\end{array}$ & $\begin{array}{l}-6.199 \\
(-0.16)\end{array}$ & $\begin{array}{c}-69.024 \\
(-1.14)\end{array}$ \\
\hline LOAN & $\begin{array}{c}-0.035^{\star \star \star} \\
(-4.97)\end{array}$ & $\begin{array}{c}-0.020^{\star \star \star} \\
(-2.73)\end{array}$ & $\begin{array}{c}-0.019^{\star \star \star} \\
(-2.63)\end{array}$ & & $\begin{array}{l}-0.009 \\
(-0.56)\end{array}$ & $\begin{array}{l}0.023 \\
(1.01)\end{array}$ & $\begin{array}{l}-0.023 \\
(-1.05)\end{array}$ & \\
\hline CAR & $\begin{array}{l}0.075 \\
(1.27)\end{array}$ & $\begin{array}{l}0.126 \\
(1.24)\end{array}$ & $\begin{array}{l}1.035 \\
(1.29)\end{array}$ & $\begin{array}{c}0.284^{\star *} \\
(2.42)\end{array}$ & $\begin{array}{l}-0.062 \\
(-0.55)\end{array}$ & $\begin{array}{l}-0.099 \\
(-0.85)\end{array}$ & $\begin{array}{c}-0.785^{\star} \\
(-1.89)\end{array}$ & $\begin{array}{l}0.120 \\
(1.29)\end{array}$ \\
\hline$\Delta \mathrm{GDP}$ & $\begin{array}{c}-0.158^{\star \star} \\
(-2.55)\end{array}$ & $\begin{array}{c}-0.160^{\star \star \star} \\
(-2.64)\end{array}$ & $\begin{array}{c}-0.217^{\star \star \star} \\
(-3.38)\end{array}$ & $\begin{array}{l}-0.006 \\
(-0.06)\end{array}$ & $\begin{array}{l}0.409^{\star \star} \\
(2.49)\end{array}$ & $\begin{array}{l}0.038 \\
(0.22)\end{array}$ & $\begin{array}{c}0.669^{\star \star \star} \\
(3.51)\end{array}$ & $\begin{array}{c}-0.310^{\star \star \star} \\
(-4.20)\end{array}$ \\
\hline$\Delta$ GDPt-1 & $\begin{array}{c}-0.348^{\star \star \star} \\
(-5.56)\end{array}$ & $\begin{array}{c}-0.275^{\star \star \star} \\
(-4.63)\end{array}$ & $\begin{array}{c}-0.287^{\star \star} \\
(-2.07)\end{array}$ & $\begin{array}{c}-0.159^{\star \star \star} \\
(-2.71)\end{array}$ & $\begin{array}{c}-0.568^{\star \star \star} \\
(-4.08)\end{array}$ & $\begin{array}{c}-0.504^{\star \star \star} \\
(-3.25)\end{array}$ & $\begin{array}{c}-0.642^{\star \star \star} \\
(-4.93)\end{array}$ & $\begin{array}{l}-0.076 \\
(-0.63)\end{array}$ \\
\hline POS & $\begin{array}{l}0.316 \\
(0.85)\end{array}$ & & & & $\begin{array}{c}-3.503^{\star \star \star} \\
(-3.25)\end{array}$ & & & \\
\hline POS*EBTP & $\begin{array}{c}104.65^{\star \star \star} \\
(2.60)\end{array}$ & & & & $\begin{array}{c}350.23^{\star \star \star} \\
(4.22)\end{array}$ & & & \\
\hline NEG & & $\begin{array}{c}0.856^{\star} \\
(1.76)\end{array}$ & & & & $\begin{array}{c}7.805^{\star \star \star} \\
(2.78)\end{array}$ & & \\
\hline NEG*EBTP & & $\begin{array}{c}-55.486 \\
(-0.47)\end{array}$ & & & & $\begin{array}{c}-184.61^{\star *} \\
(-2.36)\end{array}$ & & \\
\hline WELL & & & $\begin{array}{l}3.972 \\
(0.76)\end{array}$ & & & & $\begin{array}{l}-1.576 \\
(-0.69)\end{array}$ & \\
\hline WELL*CAR & & & $\begin{array}{l}-0.851 \\
(-1.08)\end{array}$ & & & & $\begin{array}{l}0.668^{\star} \\
(1.85)\end{array}$ & \\
\hline $\ln ($ LOAN) & & & & $\begin{array}{c}-0.082^{\star} \\
(-1.80)\end{array}$ & & & & $\begin{array}{c}0.243^{*} \\
(1.83)\end{array}$ \\
\hline J-Statistic & 19.19 & 23.27 & 16.96 & 16.32 & 21.88 & 18.11 & 22.01 & 18.80 \\
\hline $\mathrm{P}$ (J-Stat) & 0.21 & 0.08 & 0.32 & 0.29 & 0.35 & 0.580 & 0.34 & 0.65 \\
\hline $\begin{array}{c}\text { No of } \\
\text { instrument }\end{array}$ & 30 & 30 & 30 & 27 & 35 & 35 & 35 & 35 \\
\hline $\operatorname{AR}(1)$ & 0.015 & 0.007 & 0.008 & 0.04 & 0.0001 & 0.004 & 0.0002 & 0.0005 \\
\hline AR (2) & 0.578 & 0.418 & 0.055 & 0.852 & 0.639 & 0.687 & 0.796 & 0.130 \\
\hline \multicolumn{9}{|c|}{ 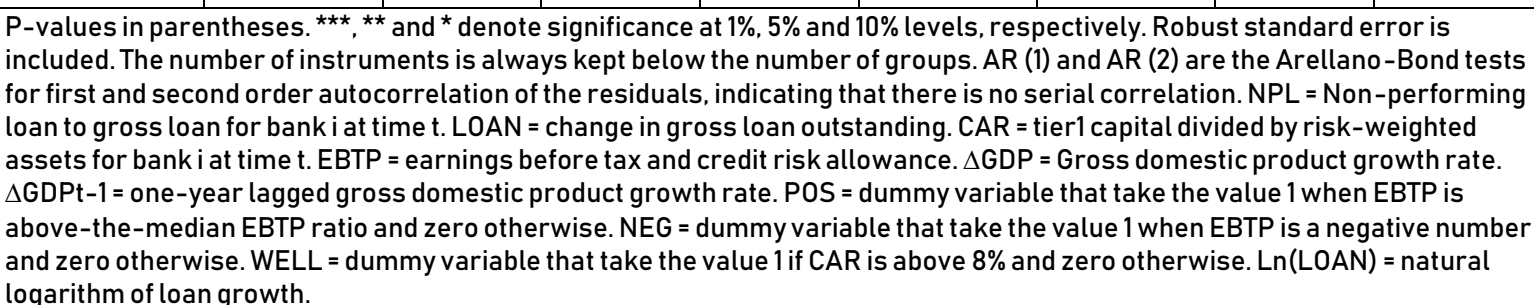 } \\
\hline
\end{tabular}




\section{Concluding Remarks}

The distinction between GSIBs and non GSIBs is driven by policy reasons. This study adopts this policy classification to investigate the relationship between nonperforming loans (NPLs) and the economic cycle for European systemic and non-systemic banks after controlling for earnings before loan loss allowance, bank lending, and bank tier 1 capital ratios. The findings reveal that systemic banks have fewer non-performing loans during economic booms. Also, increased lending is associated with few NPL in systemic banks, implying that systemic banks have a strong and prudent credit risk mitigation process that mitigates or reduce the risks in their loan portfolio while higher lending is associated with higher NPLs for non-systemic banks. Systemic banks keep higher regulatory capital when they expect higher NPLs while nonsystemic banks that exceed regulatory capital requirements experience higher NPLs. Nonsystemic banks have fewer NPLs when they experience higher losses. Finally, more profitable banks witness higher NPLs regardless of whether they are systemic or non-systemic banks.

The implication of the findings is that national supervisors need to strengthen the microprudential supervision of systemic banks in their countries to reduce abnormal NPLs to the lowest possible. To achieve this, supervisors can use a combination of micro- and macroprudential policies for banking supervision and regulation. Also, the observation that increased lending is associated with few NPLs in systemic banks but not in non-systemic banks is interesting. This calls for increased regulatory oversight on the lending practices of European banks by bank supervisors. However, bank supervisors must also exercise caution and understand that excessive focus on the supervision of systemic banks can have unintended consequences if credit risks in non-systemic banks are not monitored properly by national supervisors.

Another implication for bank supervisors is that bank supervisors should pressure all banks, both systemic and non-systemic, to improve their credit risk management systems. Bank supervisors may need to examine the credit policies of all banks and recommend a complete overhaul of the credit policies of some banks found to be weak and insensitive to credit risk. Finally, the observation that profitable banks have higher NPLs is worrying. Bank supervisors should stress-test the balance sheets of European systemic and non-systemic banks to assess whether they have sufficient capital to absorb abnormal non-performing loans without becoming insolvent. National supervisors in Europe also need to stress test the earnings power of European banks relative to the non-performing loans in their books. Future research can investigate the political, regulatory and institutional factors that influence the level of nonperforming loans in European banks such as government guarantees, regulatory forbearance, investor protection and financial crises. 


\section{Reference}

Acharya, V., Pedersen, L., Philippe, T., and Richardson, M. (2010). Measuring systemic risk. Technical report, Department of Finance, NYU

Adrian, Tobias, and Markus K. Brunnermeier, 2011, CoVaR, Staff Reports 348, Federal Reserve Bank of New York.

Aiyar, M. S., Bergthaler, Garrido, Monaghan, M. D., et al (2015). A strategy for resolving Europe's problem loans. International Monetary Fund. Available at: https://www.imf.org/external/pubs/ft/sdn/2015/sdn1519.pdf Accessed on 12 January, 2019.

Allen, L., Bali, T. G., \& Tang, Y. (2012). Does systemic risk in the financial sector predict future economic downturns? The Review of Financial Studies, 25(10), 3000-3036.

Arellano, M., \& Bond, S. (1991). Some tests of specification for panel data: Monte Carlo evidence and an application to employment equations. The review of economic studies, 58(2), 277-297.

Banulescu, G. D., \& Dumitrescu, E. I. (2015). Which are the SIFIs? A Component Expected Shortfall approach to systemic risk. Journal of Banking \& Finance, 50, 575-588.

Basel, II. (2004). International convergence of capital measurement and capital standards: a revised framework. Bank for international settlements.

Beck, R., Jakubik, P., \& Piloiu, A. (2013). Non-performing loans: What matters in addition to the economic cycle? (February 11, 2013). ECB Working Paper No. 1515. Available at SSRN: https://ssrn.com/abstract=2214971

Beck, R., Jakubik, P., \& Piloiu, A. (2013). Non-performing loans: What matters in addition to the economic cycle?

Besanko, D., \& Kanatas, G. (1996). The regulation of bank capital: Do capital standards promote bank safety? Journal of financial intermediation, 5(2), 160-183.

Benink, H., \& Wihlborg, C. (2002). The new Basel capital accord: making it effective with stronger market discipline. European Financial Management, 8(1), 103-115.

Black, Lamont, Ricardo Correa, Xin Huang, and Hao Zhou, 2013, The Systemic Risk of European Banks during the Financial and Sovereign Debt Crises, Working Paper.

Bleck, A. (2018). Regulating bank leverage. Journal of Financial Economic Policy, 10(2), 264-274.

Brownlees, C. T., \& Engle, R. (2012). Volatility, correlation and tails for systemic risk measurement. Available at SSRN, 1611229.

Carey, M. (1998). Credit risk in private debt portfolios. The Journal of Finance, 53(4), 1363-1387.

Cihák, M. M. (2007). Introduction to applied stress testing (No. 7-59). International Monetary Fund. 
Drehmann (2005) A Market Based Macro Stress Test for the Corporate Credit Exposures of UK Banks. An unpublished article, Bank of England, March 2005.

Espinoza, R. A., \& Prasad, A. (2010). Nonperforming loans in the GCC banking system and their macroeconomic effects (No. 10-224). International Monetary Fund.

European Commission, EC, (2018). Proposal for a regulation of the European parliament and of the council amending regulation (EU) No 575/2013 as regards minimum loss coverage for nonperforming exposure: Impact assessment. Accessed on: $5^{\text {th }}$ June, 2018. Available at:

European Commission, 2013, Regulation No 575/2013 on prudential requirements for credit institutions and investment firms (CRR). http://eur-lex.europa.eu/legalcontent/EN/TXT/?uri=celex:32013R0575

European Commission, 2014, Proposal for a regulation on structural measures improving the resilience of EU credit institutions, $\operatorname{COM(2014)~} 043$ final. http://eur-lex.europa.eu/legalcontent/EN/ALL/?uri=CELEX:52014PC0043

Fofack, H. L. (2005). Nonperforming loans in Sub-Saharan Africa: causal analysis and macroeconomic implications. The World Bank.

Glen, J., \& Mondragón-Vélez, C. (2011). Business cycle effects on commercial bank loan portfolio performance in developing economies. Review of Development Finance, 1(2), 150-165.

Huang, Xin, Hao Zhou, and Haibin Zhu, 2009, A Framework for Assessing the Systemic Risk of Major Financial Institutions, Journal of Banking and Finance, Vol. 33, No. 11, 2036- 2049.

Huang, Xin, Hao Zhou, and Haibin Zhu, 2012, Systemic Risk Contributions, Journal of Financial Services Research, Vol. 42, No. 1-2, 55-83

Karimalis, E. N., \& Nomikos, N. K. (2018). Measuring systemic risk in the European banking sector: A Copula CoVaR approach. The European Journal of Finance, 24(11), 944-975.

Klein, N. (2013). Non-performing loans in CESEE: Determinants and impact on macroeconomic performance (No. 13-72). International Monetary Fund.

Louzis, D. P., Vouldis, A. T., \& Metaxas, V. L. (2012). Macroeconomic and bank-specific determinants of non-performing loans in Greece: A comparative study of mortgage, business and consumer loan portfolios. Journal of Banking \& Finance, 36(4), 1012-1027.

Nkusu, M. M. (2011). Nonperforming loans and macrofinancial vulnerabilities in advanced economies (No. 11-161). International Monetary Fund.

Ozili, P. K. (2019). Non-performing loans and financial development: new evidence. The Journal of Risk Finance, 20(1), 59-81.

Ozili, P.K \& Thankom, A.G (2018). Income smoothing among European systemic and nonsystemic banks. The British Accounting Review, 50(5), 539-558. 
Pesaran, M.H., 2006. Estimation and inference in large heterogeneous panel with a multifactor error structure. Econometrica 74 (4), 967-1012.

Pesola (2005) Banking fragility and distress: An econometric study of macroeconomic determinants. Bank of Finland Research Discussion Papers, No. 13.

Quagliariello, M. (2007). Banks' riskiness over the business cycle: a panel analysis on Italian intermediaries. Applied Financial Economics, 17(2), 119-138.

Ruckes, M. (2004). Bank competition and credit standards. Review of Financial Studies, 17(4), 1073-1102.

Salas, V., \& Saurina, J. (2002). Credit risk in two institutional regimes: Spanish commercial and savings banks. Journal of Financial Services Research, 22(3), 203-224.

Shrieves, R. E., \& Dahl, D. (1992). The relationship between risk and capital in commercial banks. Journal of Banking \& Finance, 16(2), 439-457.

Wezel, T., Canta, M., \& Luy, M. (2014). A practical example of the nonperforming loans projection approach to stress testing. A Guide to IMF Stress Testing: Methods and Models, 473-483.

Appendix

\begin{tabular}{|l|l|l|l|}
\hline A1: Summary of Sample Distribution \\
\hline Country & G-SIBs & Non G-SIBs & $\begin{array}{l}\# \\
\text { Banks }\end{array}$ \\
\hline United Kingdom & 13 & 22 & 35 \\
\hline Germany & 2 & 24 & 26 \\
\hline Ireland & 1 & 9 & 10 \\
\hline Luxembourg & 2 & 5 & 7 \\
\hline Norway & 1 & 6 & 7 \\
\hline Denmark & 1 & 10 & 11 \\
\hline Finland & 1 & 3 & 4 \\
\hline Greece & 0 & 4 & 4 \\
\hline Portugal & 2 & 4 & 6 \\
\hline Belgium & 1 & 9 & 10 \\
\hline Netherland & 3 & 9 & 12 \\
\hline Sweden & 2 & 9 & 11 \\
\hline Spain & 2 & 8 & 10 \\
\hline France & 7 & 28 & 35 \\
\hline Italy & 2 & 27 & 29 \\
\hline Austria & 1 & 13 & 14 \\
\hline & & & \\
\hline Grand Total & 41 & 190 & 231 \\
\hline
\end{tabular}

